\title{
Keragaman Konsumsi Pangan dan Kejadian Anemia pada Ibu Hamil di Kabupaten Sumenep Madura
}

\section{Dietary Diversity and Anemia of Pregnant Women in Sumenep District Madura}

\author{
"Dyan Fajar Christianti, Faisal Anwar, Cesilia Meti Dwiriani \\ Departemen Gizi Masyarakat, Fakultas Ekologi Manusia, Institut Pertanian Bogor \\ (*dyanfajar38@gmail.com)
}

\begin{abstract}
ABSTRAK
Anemia pada ibu hamil di Indonesia mencapai 48,9\%. Tujuan penelitian ini adalah menganalisis hubungan antara keragaman konsumsi pangan dengan anemia pada ibu hamil di Kabupaten Sumenep, Madura. Penelitian ini menggunakan desain cross sectional. Populasi penelitian ini adalah 411 ibu hamil pada empat puskesmas terpilih di Kabupaten Sumenep. Subjek adalah ibu hamil trimester I, II, dan III sebanyak 200 ibu hamil yang dipilih secara proportional random sampling. Pengumpulan data dilakukan dengan teknik wawancara menggunakan kuesioner dan pengukuran secara langsung. Data yang digunakan terdiri atas status sosial ekonomi, riwayat kehamilan, ukuran LILA, kadar hemoglobin, dan skor Minimum Dietary Diversity-Women (MDD-W). Analisis data menggunakan uji spearman untuk menentukan hubungan antara skor MDD-W dengan kadar hemoglobin darah ibu hamil. Hasil penelitian menunjukkan bahwa 51,5\% ibu hamil mengalami anemia. Skor MDD-W kelompok anemia dan non-anemia tergolong rendah $(4,8 \pm 1,2$ vs $4,8 \pm 1,6)$. Hasil analisis spearman menunjukkan bahwa skor MDD-W tidak berhubungan dengan kadar hemoglobin $(\mathrm{p}>0,05)$. Faktor yang berhubungan signifikan dengan kadar hemoglobin, antara lain usia kehamilan ( $\mathrm{r}=-0,148 ; \mathrm{p}=0,036)$, IMT sebelum hamil $(\mathrm{r}=0,145 ; \mathrm{p}=0,041)$, dan lingkar lengan atas $(r=0,231 ; p=0,001)$. Faktor yang berhubungan dengan terjadinya anemia pada ibu hamil adalah faktor usia kehamilan, status gizi sebelum hamil, dan ukuran LILA, sedangkan keragaman konsumsi pangan tidak berhubungan dengan kejadian anemia pada ibu hamil.
\end{abstract}

Kata kunci: Kadar hemoglobin, kehamilan, LILA, MDD-W

\begin{abstract}
Pregnant women in Indonesia whose anemic reach 48,9\%. The purpose of this study was to analyze the correlation between dietary diversity and anemia in pregnant women in Sumenep District, Madura. This study was a cross-sectional design. The population of this study was 411 pregnant women in four selected health centers in Sumenep District. Subjects were all stage of pregnancy (trimester I, II, III) which numbered 200 pregnant women who were selected by proportional random sampling. Data were collected through interviews using a questionnaire and direct measurement. The data used consisted of socio-economic status, history of pregnancy, MUAC, hemoglobin concentration, and Minimum Dietary Diversity-Women (MDD-W) score. Data analysis used the spearman test to determine the correlation between $M D D-W$ score and hemoglobin concentration in pregnant women. The result showed that $51,5 \%$ of pregnant women were anemic. The $M D D$ - $W$ score for anemia and non-anemia groups was low $(4,8 \pm 1,2$ vs 4,8 1,6$)$. Spearman test showed that the MDD-W score was not associated with hemoglobin concentration $(p>0,05)$. Factors of significantly associated with haemoglobin concentration were including gestational age $(r=-0,148 ; p=0,036)$, BMI pre-pregnancy $(r=0,145 ; p=0,041)$, and mid-upper arm circumference $(r=0,231 ; p=0,001)$. Factors related to anemia in pregnant women were the gestational age, nutritional status in pre-pregnancy, and $M U A C$, while dietary diversity was not related to the incidence of anemia in pregnant women Keyword: Haemoglobin concentration, pregnancy, MUAC, MDD-W
\end{abstract}




\section{PENDAHULUAN}

Masa kehamilan umumnya berlangsung selama 40 minggu yang diawali dengan proses konsepsi pada 14 hari setelah hari pertama haid terakhir. Tahap perkembangan janin sangat penting untuk selalu diperhatikan. Masalah gizi dan kesehatan ibu selama kehamilan dapat berdampak pada bayi yang akan dilahirkan. ${ }^{1}$ Pemerintah telah mengupayakan pencapaian target untuk meningkatkan status gizi dan kesehatan ibu hamil dan bayi melalui gerakan 1000 HPK (Hari Pertama Kehidupan). Gerakan tersebut fokus pada 1000 hari pertama kehidupan yang dimulai sejak masa kehamilan (selama 270 hari), hingga anak usia 2 tahun (730 hari). Oleh sebab itu, sasaran dari gerakan 1000 HPK adalah ibu hamil, ibu menyusui, dan anak usia 0-23 tahun. ${ }^{2}$

Angka kematian ibu merupakan indikator yang digunakan untuk menentukan masalah gizi dan kesehatan ibu hamil. Angka kematian ibu di Indonesia tahun 2017 masih relatif tinggi, yaitu 305 per 100.000 kelahiran hidup. Salah satu provinsi di Indonesia dengan kasus kematian ibu terbanyak adalah Jawa Timur yang mencapai 92 per 100.000 kelahiran hidup. ${ }^{3}$ Beberapa faktor yang menjadi penyebab kematian ibu, antara lain anemia, KEK, riwayat penyakit dan komplikasi saat kehamilan. ${ }^{4}$ Ibu hamil merupakan kelompok yang rentan mengalami masalah gizi, seperti anemia dan KEK. ${ }^{5}$ Masalah anemia pada ibu hamil masih banyak terjadi baik di negara berkembang maupun negara maju. Prevalensi anemia ibu hamil di Indonesia, semakin meningkat. Data Riskesdas menunjukkan bahwa pada tahun 2013 ibu hamil mengalami anemia sebanyak $37,1 \%$, kemudian terjadi peningkatan pada tahun 2018 menjadi $48,9 \%{ }^{6,7}$ Ibu hamil yang mengalami anemia dapat berakibat pada outcome kelahiran, seperti berat lahir bayi yang rendah $(<2500 \mathrm{~g})$, kelahiran prematur, perkembangan janin yang tidak optimal, hingga kematian bayi. ${ }^{8,9}$

Perubahan fisiologi yang terjadi pada masa kehamilan juga berdampak pada kadar hemoglobin ibu. Hal tersebut disebabkan oleh peningkatan volume dan plasma darah serta penurunan kadar hematokrit dan protein plasma. Peningkatan volume dan plasma darah berfungsi untuk produksi cairan amnion, cadangan saat perdarahan, serta meningkatkan kapasitas darah untuk mengikat oksigen yang akan dialirkan ke jaringan. Peningkatan volume darah dimulai pada minggu ke-6 kehamilan, sedangkan plasma darah pada minggu ke-12 hingga trimester III. ${ }^{10}$ Anemia pada masa kehamilan ditandai dengan penurunan kadar hemoglobin darah yang berada pada level $<11 \mathrm{~g} / \mathrm{dl} .{ }^{11}$

Secara umum anemia disebabkan oleh defisiensi zat gizi, seperti zat besi, folat, vitamin A, dan vitamin B12. ${ }^{12}$ Tingkat keragaman konsumsi pangan berkaitan dengan tingkat kecukupan zat gizi. Keragaman konsumsi pangan sangat dianjurkan untuk dapat memperoleh zat gizi yang diperlukan karena tidak ada satu makanan yang mengandung semua zat gizi yang diperlukan oleh tubuh. Sebanyak 42\% ibu hamil di Indonesia memiliki tingkat keragaman konsumsi pangan kurang dari 5 jenis kelompok pangan. yang cenderung didominasi oleh serealia serta rendah konsumsi susu. ${ }^{13}$ Oleh karena besarnya dampak akibat anemia dan keragaman konsumsi pangan yang rendah terhadap kesehatan ibu dan outcome kelahiran, maka penelitian perlu dilakukan dengan tujuan menganalisis pengaruh keragaman konsumsi pangan dengan anemia pada ibu hamil.

\section{BAHAN DAN METODE}

Penelitian ini menggunakan desain cross sectional. Pengambilan data dilakukan di Kabupaten Sumenep Madura pada bulan Februari sampai Maret 2017. Populasi dalam penelitian ini adalah ibu hamil pada empat puskesmas terpilih, yaitu Puskesmas Lenteng, Puskesmas Moncek, Puskesmas Kalianget, dan Puskesmas Batang-Batang dengan total $411 \mathrm{ibu}$ hamil. Jumlah subjek pada penelitian ini sebanyak $200 \mathrm{ibu}$ hamil trimester I, II, dan III yang dihitung menggunakan rumus Lameshow et al., tahun $1990 .{ }^{14}$ Pemilihan subjek dilakukan secara proportional random sampling berdasarkan jumlah ibu hamil pada masingmasing puskesmas terpilih. Jumlah ibu hamil di Puskesmas Lenteng adalah 149 orang, Puskesmas Moncek 43 orang, Puskesmas Kalianget 128 orang, dan Puskesmas Batang-Batang 91 orang. Proporsi jumlah subjek terpilih pada masingmasing Puskesmas ditentukan berdasarkan jumlah total subjek pada penelitian ini. Berikut adalah jumlah subjek masing-masing, Puskesmas Lenteng 74 subjek (37\%), Puskesmas Moncek 24 subjek (12\%), Puskesmas Kalianget 62 subjek (31\%), 
dan Puskesmas Batang-Batang 40 subjek (20\%).

Pemilihan subjek didasarkan pada kriteria inklusi dan eksklusi. Kriteria inklusi subjek adalah ibu hamil berusia 18-49 tahun, tidak memiliki diet khusus, serta bersedia untuk berpartisipasi dengan menandatangani informed consent. Kriteria eksklusi subjek adalah ibu hamil dengan perawatan khusus akibat komplikasi selama kehamilan. Penelitian ini merupakan bagian dari penelitian $D i$ etary Intake, Nutritional Status, Traditional Beliefs and Practices of Pregnant Women in Madura Island yang didanai oleh Neys-van Hoogstraten Foundation-Netherlands. ${ }^{15}$ Penelitian ini telah mendapatkan persetujuan etik dari Komisi Etik Penelitian Kesehatan Universitas Airlangga Surabaya No. 1-KEPK.

Data yang digunakan meliputi tingkat pendidikan, status ekonomi, usia ibu hamil, usia kehamilan, paritas, jarak kelahiran, IMT sebelum hamil, ukuran LILA, kadar hemoglobin, dan keragaman konsumsi pangan. Data sosial ekonomi, riwayat kehamilan, dan keragaman konsumsi pangan diperoleh melalui wawancara menggunakan kuesioner, sedangkan data berat badan saat ini, tinggi badan, LILA, dan kadar hemoglobin diperoleh melalui pengukuran langsung. Berat badan subjek diukur menggunakan timbangan digital, tinggi badan menggunakan microtoise, dan LILA menggunakan pita LILA. Pemeriksaan kadar hemoglobin dilakukan oleh petugas Laboratorium Kesehatan Daerah (Labkesda) Kabupaten Sumenep menggunakan sampel darah yang diambil melalui vena mediana cubiti sebanyak $5 \mathrm{ml}$. Analisis dilakukan menggunakan metode cyanmethemoglobin.

Data konsumsi pangan diperoleh dari hasil recall 24 jam. Menurut Kennedy et al., tahun 2009, keragaman konsumsi pangan yang diukur dengan recall satu atau tujuh hari tidak menunjukkan perbedaan signifikan. ${ }^{16}$ Instrumen yang digunakan pada penelitian ini adalah Minimum Dietary Diversity-Women (MDD-W) yang menunjukkan jumlah kelompok pangan yang dikonsumsi oleh wanita usia subur. Instrumen tersebut dikembangkan oleh FAO tahun 2016. ${ }^{17}$ Kelompok pangan pada instrumen MDD-W terdiri atas 10 kelompok, yaitu serealia dan umbi-umbian (nasi, mie, singkong, dll); polong-polongan (buncis, kacang hijau, kacang kedelai, tahu/tempe, dll); kacang- kacangan dan biji (almond, kacang tanah, biji labu, dll); susu dan olahannya (susu, keju, yoghurt, dll); pangan hewani (daging, unggas, ikan, seafood, jeroan); telur (telur unggas atau burung); sayuran hijau (brokoli, bayam, kangkung, kelor, dll); sayur dan buah sumber vitamin A (labu kuning, wortel, ubi kuning, mangga matang, pepaya matang, dll); sayur lainnya (kol, terong, mentimun, jamur); dan buah lainnya (apel, pisang, nanas, anggur, dll).

Bahan pangan yang diperhitungkan jika jumlah yang dikonsumsi $\geq 15 \mathrm{~g}$ (sekitar 1 sendok makan). Setiap kelompok pangan diberi skor 1 jika selama 24 jam subjek mengonsumsi minimal satu bahan pangan dan 0 jika tidak mengonsumsi pangan dari kelompok tersebut. Skor MDD-W berkisar antara 1-10 yang kemudian diklasifikasikan menjadi dua kelompok, yaitu rendah (konsumsi $<5$ kelompok pangan) dan tinggi (konsumsi $\geq 5$ kelompok pangan). Pengolahan data dilakukan menggunakan Microsoft Excel 2013 dan dianalisis dengan Statistical Program for Social Science (SPSS) 22.0 for Windows. Uji Mann-Whitney dilakukan untuk mengetahui adanya perbedaan data variabel antara kelompok anemia dan non-anemia, selanjutnya untuk mengetahui variabel yang berhubungan dengan anemia pada ibu hamil dilakukan menggunakan uji spearman.

\section{HASIL}

Total responden pada penelitian ini adalah $200 \mathrm{ibu}$ hamil yang terbagi dalam kelompok anemia ( $\mathrm{n}=103$ responden; 51,5\%) dan non-anemia ( $n=97$ responden; 48,5\%). Distribusi ibu hamil yang mengalami anemia ringan sebanyak $32 \%$, $19,5 \%$ mengalami anemia sedang, dan tidak ada ibu hamil yang mengalami anemia berat $(0 \%)$ (Gambar 1).

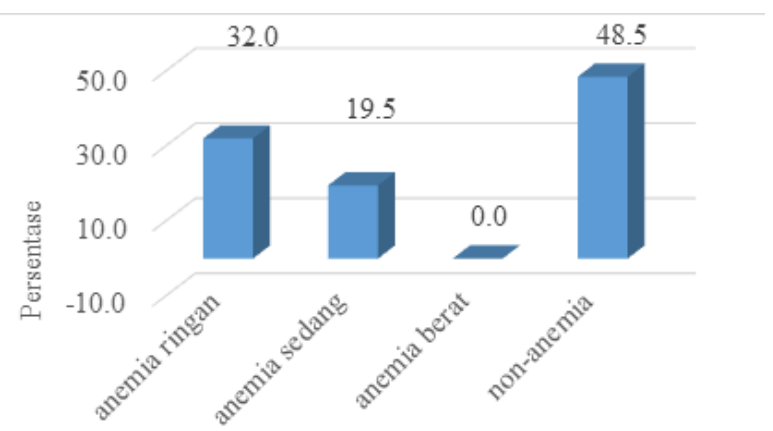

Gambar 1. Derajat Anemia Responden 
Tabel 1. Distribusi Karakteristik Responden

\begin{tabular}{|c|c|c|c|c|c|c|c|}
\hline \multirow{2}{*}{ Karakteristik } & \multicolumn{3}{|c|}{ Anemia } & \multicolumn{3}{|c|}{ Non anemia } & \multirow{2}{*}{ Pvalue } \\
\hline & $\mathrm{n}=\mathbf{1 0 3}$ & $\%$ & $\mathbf{x} \pm \mathbf{s d}$ & $\mathbf{n}=\mathbf{9 7}$ & $\%$ & $\mathbf{x} \pm \mathbf{s d}$ & \\
\hline Tingkat pendidikan (tahun) & & & $10,8 \pm 3,5$ & & & $10,2 \pm 3,7$ & 0,283 \\
\hline Rendah $(<9)$ & 25 & 24,3 & & 32 & 33,0 & & \\
\hline Menengah (9-11) & 22 & 21,4 & & 17 & 17,5 & & \\
\hline Tinggi $(\geq 12)$ & 56 & 54,4 & & 48 & 49,5 & & \\
\hline Status ekonomi (Rp 000) & & & $500 \pm 320$ & & & $453 \pm 207$ & 0,706 \\
\hline Miskin & 27 & 26,2 & & 26 & 26,8 & & \\
\hline Tidak miskin & 76 & 73,8 & & 71 & 73,2 & & \\
\hline Usia (tahun) & & & $25,9 \pm 5,3$ & & & $26,7 \pm 5,5$ & 0,243 \\
\hline$<20$ & 11 & 10,7 & & 8 & 8,2 & & \\
\hline $20-35$ & 86 & 83,5 & & 81 & 83,5 & & \\
\hline$>35$ & 6 & 5,8 & & 8 & 8,2 & & \\
\hline Usia kehamilan (minggu) & & & $24,1 \pm 7,4$ & & & $22,0 \pm 7,6$ & $0,025^{*}$ \\
\hline Trimester I (0-12) & 9 & 8,7 & & 15 & 15,5 & & \\
\hline Trimester II (13-26) & 46 & 44,7 & & 54 & 55,7 & & \\
\hline Trimester III (27-40) & 48 & 46,6 & & 28 & 28,9 & & \\
\hline Paritas (kali) & & & $0,7 \pm 0,7$ & & & $0,9 \pm 1,0$ & 0,128 \\
\hline Nulliparous $(0)$ & 50 & 48,5 & & 38 & 39,2 & & \\
\hline Primiparous (1) & 39 & 37,9 & & 41 & 42,3 & & \\
\hline Multiparous $(\geq 2)$ & 14 & 13,6 & & 18 & 18,6 & & \\
\hline Jarak kelahiran (tahun) & & & $3,5 \pm 4,1$ & & & $3,9 \pm 4,0$ & 0,274 \\
\hline 0 (hamil pertama) & 48 & 46,6 & & 36 & 37,1 & & \\
\hline$<2$ & 3 & 2,9 & & 5 & 5,2 & & \\
\hline$\geq 2$ & 52 & 50,5 & & 56 & 57,7 & & \\
\hline IMT pra hamil (kg/m2) & & & $21,5 \pm 3,8$ & & & $23,1 \pm 5,1$ & 0,055 \\
\hline Kurus: $<18.5$ & 18 & 17,5 & & 20 & 20,6 & & \\
\hline Normal: 18.5-24.9 & 68 & 66,0 & & 42 & 43,3 & & \\
\hline Overweight: $25.0-29.9$ & 13 & 12,6 & & 24 & 24,7 & & \\
\hline Obese: $\geq 30.0$ & 4 & 3,9 & & 11 & 11,3 & & \\
\hline LILA & & & $25,4 \pm 2,9$ & & & $27,2 \pm 4,3$ & $0,005^{*}$ \\
\hline $\operatorname{KEK}(<23.5 \mathrm{~cm})$ & 24 & 23,3 & & 14 & 14,4 & & \\
\hline $\operatorname{Normal}(\geq 23.5 \mathrm{~cm})$ & 79 & 76,7 & & 83 & 85,6 & & \\
\hline Skor MDD-W & & & $4,8 \pm 1,2$ & & & $4,8 \pm 1,6$ & 0,891 \\
\hline$<5$ kelompok pangan & 46 & 44,7 & & 45 & 46,4 & & \\
\hline$\geq 5$ kelompok pangan & 57 & 55,3 & & 52 & 53,6 & & \\
\hline
\end{tabular}

Sumber : Data Primer, 2017

*Uji Mann-Whitney signifikan pada $\mathrm{p}<0,05$

Distribusi karakteristik responden berdasarkan tingkat pendidikan pada kelompok anemia maupun non-anemia tergolong tinggi atau setara dengan lulusan SMA, masing-masing 54,4\% dan 49,5\%. Hasil uji Mann-Whitney menunjukkan tidak ada perbedaan tingkat pendidikan pada kelompok anemia dan non-anemia $(\mathrm{p}>0,05)$. Status ekonomi pada sebagian besar responden tergolong tidak miskin dan tidak terdapat perbedaan antara kelompok anemia dan non-anemia. Ratarata pendapatan per kapita per bulan pada kelom- pok anemia lebih tinggi dibandingkan non-anemia, masing-masing adalah Rp 500.000 \pm 320.000 dan $\mathrm{Rp}$ 453.000 \pm 207.000 . Rata-rata usia responden kelompok anemia lebih rendah $(25,9 \pm 5,3$ tahun) dibandingkan dengan kelompok non-anemia (26,7 $\pm 5,5$ tahun). Usia responden kelompok anemia dan non-anemia tidak menunjukkan adanya perbedaan $(\mathrm{p}>0,05)($ Tabel 1).

Berdasarkan usia kehamilan dan riwayat kehamilan responden menunjukkan bahwa responden yang mengalami anemia lebih banyak 
ditemukan pada kehamilan trimester III, yaitu $46,6 \%$, sedangkan sebagian besar responden non-anemia $(55,7 \%)$ berada pada trimester II. Hasil uji Mann-Whitney menunjukkan adanya perbedaan signifikan usia kehamilan pada kelompok anemia dan non-anemia $(p=0,025)$. Sebagian besar responden kelompok anemia $(48,5 \%)$ tergolong nulliparous atau belum pernah melahirkan, sedangkan 42,3\% responden pada kelompok anemia tergolong primiparous. Uji Mann-Whitney menunjukkan tidak ada perbedaan paritas antara kelompok anemia dan non-anemia $(\mathrm{p}>0.05)$. Ratarata jarak kelahiran responden lebih dari 2 tahun, yaitu 3,5 $\pm 4,1$ tahun pada kelompok anemia dan $3,9 \pm 4,0$ tahun pada kelompok non-anemia. Uji Mann-Whitney menunjukkan tidak ada perbedaan jarak kelahiran pada kelompok anemia dan non-anemia $(\mathrm{p}>0,05)$ (Tabel 1).

Status gizi responden ditentukan berdasarkan Indeks Massa Tubuh (IMT) sebelum hamil dan ukuran lingkar lengan atas (LILA) saat ini. Sebagian besar IMT responden sebelum hamil termasuk dalam kategori normal dengan rata-rata IMT kelompok anemia lebih rendah $(21,5 \pm 3,8 \mathrm{~kg} /$ $\left.\mathrm{m}^{2}\right)$ dibandingan kelompok non-anemia $(23,1 \pm 5,1$ $\mathrm{kg} / \mathrm{m}^{2}$ ). Responden dengan IMT $<18,5 \mathrm{~kg} / \mathrm{m}^{2}$ ditemukan pada kedua kelompok, masing-masing $17,5 \%$ pada kelompok anemia dan $20,6 \%$ pada kelompok non-anemia. Status gizi overweight dan obese sebelum hamil lebih banyak ditemukan pada kelompok non-anemia (36\%). Hasil uji Mann-Whitney menunjukkan tidak terdapat perbedaan IMT sebelum hamil pada kelompok anemia dan non-anemia $(\mathrm{p}>0,05)$. Ukuran lingkar lengan atas (LILA) digunakan untuk menentukan status KEK ibu hamil. LILA responden pada kelompok anemia lebih rendah $(25,4 \pm 2,9 \mathrm{~cm})$ dibandingkan kelompok non-anemia $(27,2 \pm 4,3 \mathrm{~cm})$. Hasil uji Mann-Whitney menunjukkan adanya perbedaan ukuran LILA pada kelompok anemia dan non-anemia $(p=0,005)$.

Rata-rata skor keragaman konsumsi pangan (MDD-W) pada kelompok anemia dan non-anemia tergolong rendah, masing-masing 4,8 $\pm 1,2$ dan $4,8 \pm 1,6$. Kelompok pangan yang banyak dikonsumsi oleh responden kelompok anemia dan non-anemia tidak jauh berbeda dan hasil uji Mann-Whitney menunjukkan tidak ada perbedaan skor MDD-W pada kelompok anemia dan

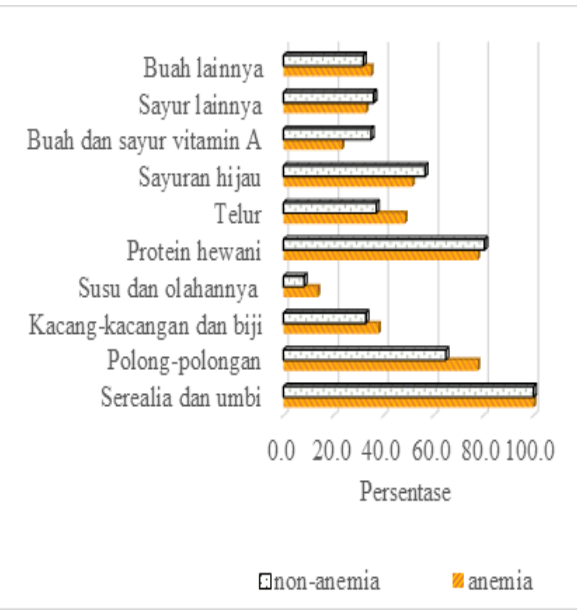

\section{Gambar 2. Distribusi Konsumsi Pangan Res- ponden Berdasarkan Kelompok Pangan}

non-anemia $(p>0,05)($ Tabel 1).

Distribusi konsumsi pangan responden berdasarkan kelompok pangan adalah sebagai berikut, serealia dan umbi-umbian dikonsumsi oleh seluruh responden kelompok anemia dan non anemia. Kelompok pangan berikutnya yang banyak dikonsumsi oleh responden kelompok anemia dan non-anemia, berturut-turut adalah protein hewani $(77,7 \%$ vs $80,4 \%)$, polong-polongan $(77,7 \%$ vs $64,9 \%$ ), sayuran hijau (51,5\% vs 56,7\%), dan telur (48,5\% vs $37,1 \%)$. Kelompok pangan yang paling sedikit dikonsumsi oleh responden kelompok anemia maupun non-anemia adalah susu $(13,5 \%$ vs 8,2\%) (Gambar 2).

Faktor yang berhubungan dengan status anemia (kadar hemoglobin) responden diperoleh melalui uji spearman. Usia kehamilan $(\mathrm{r}=0,148 ; \mathrm{p}=0.036)$, IMT sebelum hamil $(\mathrm{r}=0,145$;

Tabel 2. Hubungan Karakteristik Umum Responden dengan Status Anemia

\begin{tabular}{lcc}
\hline \multicolumn{1}{c}{ Karakteristik } & $\mathbf{r}$ & $\mathbf{p}$ \\
\hline Tingkat pendidikan & $-0,043$ & 0,544 \\
Status ekonomi & $-0,042$ & 0,556 \\
Usia & 0,060 & 0,402 \\
Usia kehamilan & $-0,148$ & 0,036 \\
Paritas & 0,061 & 0,390 \\
Jarak kehamilan & 0,044 & 0,536 \\
IMT pra hamil & 0,145 & 0,041 \\
LILA & 0,231 & 0,001 \\
Skor MDD-W & 0,002 & 0,980 \\
\hline Sti Da Pin
\end{tabular}


$\mathrm{p}=0,041)$, dan LILA $(\mathrm{r}=0,231 ; \mathrm{p}=0,001)$ menunjukkan hubungan yang signifikan dengan kadar hemoglobin responden. Tingkat pendidikan, status ekonomi, usia responden, paritas, jarak kelahiran, dan skor MDD-W tidak berhubungan dengan kadar hemoglobin responden ( $>00,05)$ (Tabel 2).

\section{PEMBAHASAN}

Anemia ibu hamil pada penelitian ini sebesar 51,5\%. Jumlah tersebut lebih tinggi jika dibandingkan dengan anemia ibu hamil di Indonesia tahun $2018(48,9 \%)$ dan lebih rendah dibandingkan dengan anemia ibu hamil di Kabupaten Sampang $(61,5 \%))^{7,18}$ Perbedaan prevalensi anemia ibu hamil dipengaruhi oleh berbagai faktor, diantaranya usia, tingkat pendidikan, sosial ekonomi keluarga, usia kehamilan, paritas, jarak kelahiran, status gizi, adanya penyakit infeksi, dan konsumsi pangan. ${ }^{19-21}$

Faktor sosial ekonomi (tingkat pendidikan dan status ekonomi) pada penelitian ini tidak menunjukkan adanya hubungan dengan status anemia ibu hamil. Berbeda dengan penelitian di Ethiopia yang menunjukkan adanya hubungan tingkat pendidikan dan status ekonomi dengan anemia ibu hamil. ${ }^{20}$ Perbedaan hasil penelitian tersebut disebabkan oleh kondisi sosial ekonomi kelompok anemia dan non-anemia pada penelitian ini tidak berbeda signifikan. Alokasi pengeluaran nonpangan responden lebih tinggi $(53,3 \%)$ dibandingkan dengan pengeluaran pangan. Hal tersebut dapat berdampak pada ketersediaan pangan rumah tangga dan asupan zat gizi yang tidak mencukupi. Keluarga dengan tingkat pendapatan yang rendah cenderung untuk mengutamakan penyediaan makanan pokok, bahan pangan dengan kualitas rendah, serta terbatasnya ketersediaan sayur, buah, dan pangan hewani. ${ }^{22}$

Usia dapat berpengaruh terhadap kesiapan mental dan fisiologi ibu hamil. Responden yang mengalami anemia pada penelitian ini lebih banyak ditemukan pada rentang usia 20-35 tahun (usia tidak berisiko). Hal tersebut tidak sesuai dengan literatur yang menyatakan bahwa risiko anemia ibu hamil lebih tinggi 4,125 kali pada usia berisiko ( $<20$ tahun atau $>35$ tahun) dibandingkan dengan ibu hamil dengan usia tidak berisiko. ${ }^{23}$

Usia kehamilan menunjukkan hubungan signifikan negatif dengan kadar hemoglobin, art- inya semakin tinggi usia kehamilan maka kadar hemoglobin ibu hamil akan semakin rendah. Hal tersebut berkaitan dengan faktor fisologis kehamilan bahwa peningkatan volume darah dan plasma darah yang mengakibatkan penurunan kadar hematokrit dan protein plasma terjadi pada minggu ke-6 kehamilan hingga trimester III..$^{10}$ Oleh sebab itu, responden yang mengalami anemia pada penelitian ini lebih banyak ditemukan pada usia kehamilan trimester III. Hal tersebut sejalan dengan peneltian Melku et al. yang juga menyatakan bahwa anemia lebih banyak ditemukan pada trimester III. $^{20}$

Riwayat kehamilan, seperti paritas dan jarak kehamilan tidak menunjukkan hubungan signifikan dalam penelitian ini. Hal tersebut disebabkan oleh data paritas dan jarak kehamilan pada kelompok anemia dan non-anemia tidak berbeda signifikan. Paritas yang tinggi dan jarak kehamilan yang dekat lebih cenderung mengalami anemia karena zat besi yang keluar melalui darah saat proses persalinan belum dapat terpenuhi. Ketika kondisi ibu kembali hamil maka kebutuhan zat besi juga meningkat, sehingga kebutuhan zat gizi akan meningkat pula. ${ }^{24}$

Status gizi ibu sebelum hamil merupakan faktor risiko terhadap kesehatan ibu dan janin hingga masa dewasa. ${ }^{25,26} \mathrm{Ibu}$ dengan status gizi kurang sebelum hamil berdampak pada kelahiran prematur dan berat lahir rendah yang disebabkan oleh defisiensi zat gizi secara langsung. ${ }^{27}$ Hasil penelitian ini menunjukkan adanya hubungan signifikan positif antara status gizi ibu sebelum hamil dengan status anemia, artinya semakin baik status gizi sebelum hamil maka status anemia juga semakin baik. Hal tersebut berkaitan dengan cadangan zat gizi ibu yang baik pada sebelum hamil akan memudahkan untuk dapat mencukupi peningkatan kebutuhan zat gizi pada masa kehamilan. ${ }^{28}$ Penelitian yang dilakukan di Bali menunjukkan pemenuhan kebutuhan zat besi yang cukup melalui pemberian tablet besi pada masa prakonsepsi dapat menurunkan risiko anemia dibandingkan dengan pemberian tablet besi pada awal kehamilan. ${ }^{29}$

Status KEK yang ditentukan berdasarkan hasil pengukuran LILA menunjukkan hubungan signifikan positif dengana anemia, artinya semakin tinggi ukuran LILA maka kadar hemoglobin darah juga semakin tinggi. Ibu hamil yang mengalami 
KEK berisiko 3 kali lipat mengalami anemia. ${ }^{5,30}$ KEK pada ibu hamil dipengaruhi oleh kondisi kesehatan sebelum hamil akibat dari asupan energi yang tidak mencukupi kebutuhan dalam waktu yang cukup lama. Ketika seseorang mengalami KEK maka berat badan dan simpanan energi menjadi berkurang. Faktor konsumsi pangan sangat berpengaruh terhadap status gizi ibu. Konsumsi pangan yang rendah menyebabkan kecukupan zat gizi tidak terpenuhi.

Upaya untuk mengatasi anemia ibu hamil telah dilakukan dengan pemberian tablet besifolat. Cakupan penerimaan tablet besi-folat pada ibu hamil di Sumenep cukup tinggi, yaitu $81,6 \%$, akan tetapi penyerapan zat besi dipengaruhi oleh faktor inhibitor dan enhancer. Pangan nabati yang umumnya mengandung zat besi non heme, polifenol, dan fitat menjadi faktor inhibitor penyerapan zat besi, sedangkan untuk meningkatkan penyerapan zat besi diperlukan vitamin $\mathrm{C}$ dan konsumsi protein hewani yang banyak mengandung besi heme. ${ }^{31,32}$ Anemia ibu hamil pada penelitian ini dipengaruhi oleh pola konsumsi pangan yang meskipun tinggi konsumsi pangan hewani (ikan), tetapi konsumsi pangan nabati, terutama kelompok polong-polongan juga tinggi. Jenis bahan pangan dari kelompok polong-polongan yang banyak dikonsumsi oleh responden adalah tahu dan tempe. Selain itu, konsumsi sayur dan buah yang merupakan sumber vitamin $\mathrm{C}$ cukup rendah pada kelompok anemia. Ibu hamil yang sering mengonsumsi sayur dan buah memiliki tingkat kecukupan vitamin $C$ yang cukup. ${ }^{33}$

Skor MDD-W tidak berhubungan dengan kadar hemoglobin responden karena skor tersebut tidak menunjukkan perbedaan yang signifikan pada kedua kelompok tersebut. Meskipun hasil uji statistik tidak menunjukkan perbedaan yang signifikan pada skor MDD-W responden, tetapi ditemukan adanya perbedaan kelompok pangan yang banyak dikonsumsi oleh responden anemia dan non-anemia. Kelompok pangan yang menjadi sumber zat besi atau enhancer penyerapan zat besi lebih banyak dikonsumsi oleh kelompok non-anemia, seperti protein hewani, sayuran hijau, buah dan sayur sumber vitamin A, dan sayuran lainnya. Sementara itu, kelompok anemia lebih banyak mengonsumsi kelompok pangan yang menjadi inhibitor penyerapan zat besi, seperti polong-polongan, kacang-kacangan, dan susu. Penelitian lain menunjukkan bioavailabilitas besi pada ibu hamil di Tangerang tergolong rendah $(3,3 \pm 1,4)$, hal tersebut dipengaruhi oleh tingginya konsumsi nasi, kacang-kacangan, dan teh. ${ }^{34}$

Jenis makanan pokok responden adalah nasi atau nasi jagung. Nasi jagung merupakan campuran beras putih dengan sedikit jagung giling. Protein hewani yang dikonsumsi oleh sebagian besar responden berasal dari ikan dan telur. Tempat tinggal responden yang sebagian besar merupakan daerah pesisir dan harga yang relatif murah menyebabkan konsumsi ikan lebih tinggi dibandingkan pangan hewani lainnya. Selain ikan, harga telur, tahu, dan tempe juga lebih terjangkau dan mudah cara pengolahannya sehingga banyak dikonsumsi oleh responden. Sayuran hijau yang banyak dikonsumsi adalah daun kelor karena tanaman kelor umumnya ditanam di pekarangan sehingga mudah untuk mendapatkannya.

Budaya memiliki pengaruh terhadap konsumsi pangan masyarakat setempat. Ada beberapa jenis bahan pangan yang dianggap tabu oleh masyarakat untuk dikonsumsi pada keadaan tertentu, seperti saat kehamilan. Alasan yang diberikan oleh masyarakat hanya terbatas pada pengalaman dan nasihat orang terdahulu yang sebagian besar tidak bersifat ilmiah. Budaya terkait kehamilan seperti larangan untuk mengonsumsi pangan tertentu atau pangan tabu pada ibu hamil dapat menyebabkan asupan zat gizi ibu tidak mencukupi kebutuhan, padahal ibu hamil memerlukan berbagai zat gizi untuk menjaga kesehatannya dan perkembangan janin. ${ }^{35}$ Adanya kepercayaan terhadap pangan tabu sangat memengaruhi pemilihan jenis pangan yang akan dikonsumsi oleh ibu hamil. ${ }^{36}$ Ibu hamil memerlukan makanan yang beragam, seperti susu, buah, sayur, daging, ikan, kacang-kacangan, dan makanan pokok sehingga tidak ada alasan untuk menghindari makanan tertentu selama masa kehamilan.

Tingkat keragaman pangan berkaitan dengan tingkat kecukupan zat gizi. Oleh sebab itu, konsumsi pangan yang beragam harus disertai dengan jumlah asupan yang sesuai dengan kebutuhan agar dapat mencapai status gizi yang ideal. ${ }^{37}$ Penelitian yang dilakukan di Uganda terkait dengan norma budaya, mitos, dan pangan tabu untuk ibu dengan membatasi pangan hewani menyebab- 
kan asupan protein dan zat gizi mikro tidak terpenuhi yang dapat berdampak pada kesehatan ibu dan anak. ${ }^{38}$ Penelitian lain juga menunjukkan bahwa ibu hamil dengan tingkat keragaman konsumsi pangan yang rendah dapat meningkatkan risiko anemia. ${ }^{19,39}$

\section{KESIMPULAN DAN SARAN}

Lebih dari separuh ibu hamil di Sumenep mengalami anemia. Faktor yang berhubungan dengan status anemia pada ibu hamil, antara lain usia kehamilan, status gizi sebelum hamil, dan LILA. Keragaman konsumsi pangan tidak menunjukkan hubungan signifikan terhadap status anemia ibu hamil. Status gizi ibu sebelum hamil sangat perlu diperhatikan. Agar status gizi dalam kategori normal sejak masa prakonsepsi dapat dilakukan edukasi gizi untuk calon pengantin. Peningkatan keragaman konsumsi pangan ibu hamil perlu dilakukan untuk dapat mencukupi kebutuhan zat gizi selama kehamilan, terutama daging, susu, sayuran hijau, serta sayur dan buah sumber vitamin A. Selain itu, sosialisasi terkait pangan sumber protein hewani, zat besi, folat dan vitamin $\mathrm{C}$ perlu disampaikan kepada ibu hamil dan anggota keluarga lain, seperti suami, ibu, dan mertua yang berpengaruh terhadap pemilihan makanan ibu hamil. Dengan demikian, maka penyerapan zat besi dapat ditingkatkan sehingga dapat mengurangi risiko anemia pada ibu hamil.

\section{UCAPAN TERIMA KASIH}

Ucapan terima kasih disampaikan kepada Neys-van Hoogstraten Foundation-Netherlands yang telah mendanai penelitian ini dengan grant number IN282, Dinas Kesehatan Kabupaten Sumenep, Laboratorium Kesehatan Daerah Kabupaten Sumenep, dan bidan Puskesmas Lenteng, Moncek, Kalinget, dan Batang-Batang.

\section{DAFTAR PUSTAKA}

1. Brown, JE. Isaacs JS, Krinke UB, Lechtenberg E, Murtaugh MA, Sharbaugh C, Splett PL SJ. Nutrution Through the Life Cycle. 4 ed. California: Cengange Learning; 2011. 296-309.

2. Bappenas. Pedoman Perencanaan Program Gerakan Nasional Percepatan Perbaikan Gizi dalam Rangka Seribu Hari Pertama Kehidupan (Gerakan 1000 HPK). Jakarta: Bap- penas; 2013.

3. Dinas Kesehatan Propinsi Jawa Timur. Profil Kesehatan Propinsi Jawa Timur 2017. Dinas Kesehatan Provinsi Jawa Timur. Surabaya: Dinas Kesehatan Provinsi Jawa Timur; 2018. 29.

4. Ikhtiar M, Yasir Y. Analysis of Maternal Mortality Determinants in Gowa District South Sulawesi Province, Indonesia. Am J Public Heal Res. 2015;3(3):113-5.

5. Aminin, Fidyah AW, Lestari RP. Pengaruh Kekurangan Energi Kronis (KEK) dengan Kejadian Anemia pada Ibu Hamil. J Kesehat. 2014;5(2):167-72.

6. Kementerian Kesehatan Republik Indonesia. Hasil Riset Kesehatan Dasar Kementerian RI 2013. Vol. 6, Kementerian Kesehatan Republik Indonesia. Jakarta; 2013.

7. Kementerian Kesehatan Republik Indonesia. Hasil Utama Riskesdas 2018. Jakarta; 2018.

8. Bedi R, Acharya R, Gupta R, Pawar S, Sharma R. Maternal Factors of Anemia in 3rd Trimester of Pregnancy and Its Association with Fetal Outcome. Int Multispecialty $\mathrm{J}$ Heal. 2015;1(7):9-16.

9. Rahmati S, Delpishe A, Azami M, Hafezi Ahmadi MR, Sayehmiri K. Maternal Anemia During Pregnancy and Infant Low Birth Weight: A Systematic Review and Meta-analysis. Int $\mathrm{J}$ Reprod Biomed (Yazd, Iran). 2017;15(3):125-34.

10. Rathod N. Anemia in Pregnancy. In: High Risk Cases in Obstetrics. New Delhi; 2014. 13-32.

11. WHO. Haemoglobin Concentrations for the Diagnosis of Anaemia and Assessment of Severity [Internet]. 2011. Tersedia pada: http:// www.who.int/vmnis/indicators/haemoglobin.

12. Bekele A, Tilahun M, Mekuria A. Prevalence of Anemia and Its Associated Factors among Pregnant Women Attending Antenatal Care in Health Institutions of Arba Minch Town, Gamo Gofa Zone, Ethiopia: A Cross-Sectional Study. Anemia. 2016:1-9.

13. Rosmalina Y, E L. Besaran Keragaman dan Kualitas Konsumsi Bahan Makanan pada Ibu Hamil di Indonesia. Penelit Gizi dan Makanan. 2016;39(1):65-73.

14. Lemeshow S, Hosmer Jr DW, Klar J, Lwanga SK. Adequacy of Sample Size in Health Stud- 
ies. Adequacy of Sample Size in Health Studies. New York: WHO; 1990.

15. Diana R, Rachmayanti R, Anwar F, Khomsan A, Christianti D, Kusuma R. Dietary Intake, Nutritional Status, Traditional Beliefs and Practices of Pregnant Women in Madura Island. Surabaya; 2016.

16. Kennedy GL, Brouwer ID, Dop M, Kok FJ. Analysis of Dietary Diversity Scores Constructed from a Reference Period of One or Seven Days in an Area of Acute Food Security in Somalia. Evaluation of Dietary Diversity Scores for Assessment of Micronutrient Intake and Food Security in Developing Countries. [Wageningen]: Wegeningen University; 2009.

17. FAO and FHI 360. Minimum Dietary Diversty for Women: A Guide to Measurement. Roma: FAO; 2016.

18. Mahirawati VK. Faktor-Faktor yang Berhubungan dengan Kekurangan Energi Kronis (KEK) pada Ibu Hamil di Kecamatan Kamoning dan Tambelangan, Kabupaten Sampang, Jawa Timur. Bul Penelit Sist Kesehat. 2014;17(2):193-202.

19. Abriha A, Yesuf M, Wassie M. Prevalence and Associated Factors of Anemia among Pregnant Women of Mekelle Town: a Cross Sectional Study. BMC Res Notes. 2014;7(1):888.

20. Melku, M., Addis, Z., Alem, M. \& Enawgaw B. Prevalence and Predictors of Maternal Anaemia during Pregnancy in Gondar, Northwest Ethiopia: An Institutional Based Cross-Sectional Study. Hindawi Publ. 2014:1-9.

21. Mekonnen FA, Ambaw YA, Neri GT. Socio-Economic Determinants of Anemia in Pregnancy in North Shoa Zone, Ethiopia. PLoS One. 2018;13(8):1-9.

22. Chakona G, Shackleton C. Minimum Dietary Diversity Scores for Women Indicate Micronutrient Adequacy and Food Insecurity Status in South African Towns. Nutrients. 2017;9(812):1-16.

23. Abrori, Hutagalung K, Marlenywati. Faktor Anemia Ibu Hamil di Puskesmas Putussibau Selatan. J Vokasi Kesehat. 2015;1(4):99-104.

24. Handayani TR. Determinan Kejadian Anemia Defisiensi Zat Besi pada Ibu Hamil di Puskesmas Nagaswidak Palembang Tahun 2017. In: Proceeding Stikes Muhammadiyah Palem- bang. 2017. 345-56.

25. Schack-Nielsen L, Michaelsen KF, Gamborg M, Mortensen EL, Sørensen TIA. Gestational Weight Gain in Relation to Offspring Body Mass Index and Obesity from Infancy Through Adulthood. Int J Obes. 2010;34(1):67-74.

26. Kruger HS, Butte NF. Nutrition in Pregnancy and Lactation. Nutr Bone Heal. 2015;111:16182.

27. Han Z, Lutsiv O, Mulla S, McDonald SD. Maternal Height and the Risk of Preterm Birth and Low Birth Weight: A Systematic Review and Meta-Analyses. J Obstet Gynaecol Canada. 2012;34(8):721-46.

28. Swamilaksita PD. Efikasi Suplementasi Zat Gizi Pada Ibu Hamil Terhadap Hasil Kehamilan. Media Gizi Mikro Indones. 2016;8(1):2742.

29. Ani LS, Bakta IM, Suryadhi I, Bagiada A. Perbandingan Efek Suplemen Besi Pra-Hamil dan Selama Kehamilan dalam Upaya Menurunkan Anemia Defisiensi Besi pada Wanita Hamil dengan Anemia Ringan. Indones J Biomed Sci. 2008;1(3):1-18.

30. Marlapan S. Hubungan Status Gizi dengan Kejadian Anemia pada Ibu Hamil di Wilayah Kerja Puskesmas Tuminting Kec. Tuminting Kota Manado. Ejournal Keperawatan. 2013;1(1):1-7.

31. Hurrel R, Egli I. Iron Bioavailability and Dietary Reference Values. Am J Clin Nutr. 2010;91(5):1461-7.

32. Geissler C, Singh M. Iron, Meat and Health. Nutrients. 2011;3(3):283-316.

33. Indriasari R, Salam A, Sriwahyuni. Pola Konsumsi Buah Dan Sayur serta Asupan Zat Gizi Mikro dan Serat pada Ibu Hamil Di Kabupaten Gowa 2013 [Internet]. 2013. Tersedia pada: http://repository.unhas.ac.id/bitstream/ handle/123456789/5457/Jurnal MKMI.pdf? sequence $=1$.

34. Fitri YP, Briawan D, Tanziha I, Madanijah S. Tingkat Kecukupan dan Bioavailabilitas Asupan Zat Besi pada Ibu Hamil Di Kota Tangerang. Media Kesehat Masy Indones. 2016;12(3):185-91.

35. Catherin N, Rock B, Rock V, Ankita C, Ashish G, Delwin P, et al. Beliefs and practices regarding nutrition during pregnancy and 
lactation in a rural area in Karnataka, India: a qualitative study. Int J Community Med Public Heal. 2015;2(2):116.

36. Ezeama MC, Ezeamah I. Attitude and socio-cultural practice during pregnancy among women in Akinyele L. G. A. of Oyo State, Nigeria. J Res Nurs Midwifery. 2014;3(1):14-20

37. County L, Willy K, Judith K, Peter C. Dietary Diversity, Nutrient Intake and Nutritional Status among Pregnant International Journal of Health Sciences and Research Dietary Diversity, Nutrient Intake and Nutritional Status among Pregnant Women in Laikipia County, Kenya. Int J Helalth Sci Res. 2016;6(4):37885.

38. Muggaga C, Ongeng D, Mugonola B, Okello-Uma I, Kaaya NA, Taylor D. Influence of Sociocultural Practices on Food and Nutrition Security in Karamoja Subregion of Uganda. Ecol Food Nutr. 2017;56(5):424-47.

39. Zerfu TA, Umeta M, Baye K. Dietary Diversity During Pregnancy is Associated with Reduced Risk of Maternal Anemia, Preterm Delivery, and Low Birth Weight in a Prospective Cohort Study in Rural Ethiopia. Am J Clin Nutr. 2016;103:1482-8. 